metabolism in cardiac muscle. In Fozzard $\mathrm{H}$, et al., eds. The Heart and Cardiovascular System. New York, Raven.

Van Calker P, Muller M, Hamprecht B: 1979. Adenosine regulates via two different receptors, the accumulation of cyclic AMP in cultured brain cells. J Neurochem 33:9991005.

Visentin S, Wu S-N, Belardinelli L: 1990. Adenosine-induced changes in atrial action potential: contribution of $\mathrm{Ca}$ and $\mathrm{K}$ currents. Am J Physiol 258:H1070-H1078.

Wesley RC, Belardinelli L: 1985. Role of adenosine on ventricular overdrive suppression in isolated guinea pig hearts and purkinje fibers. Circ Res 57:517-531.

Wilson RF, Wyche $\mathrm{K}$, Christensen BV,

Zimmer S, Laxson DD: 1990. Effects of adenosineon human coronary arterial circulation. Circulation 82:1595-1606.

Wu SN, Linden J, Visentin S, Boykin M, Belardinelli L: 1991. Enhanced sensitivity of heart cells to adenosine and upregulation of receptor number after treatment of guinea pigs with theophylline. Circ Res 65:1066-1077.

Xu D, Kong H, Liang BT: 1992. Expression and pharmacological characterization of a stimulatory subtype of adenosine receptor in ventricular myocyte. Circ Res 70:56-65.

Zhang Y, Wells JN: 1990. Effects of chronic caffeine administration on peripheral adenosine receptors. J Pharmacol Exp Ther 254:270-276.

TCM

\title{
Modulation of the Cell Membrane Expression of the Kininogens Regulates the Rate of Bradykinin Delivery to Cells
}

\author{
Alvin H. Schmaier
}

The kininogens were first recognized as the parent molecules for bradykinin. Their relative physiologic importance in plasma hemostasis and fibrinolysis and tissue cysteine protease inhibition has not been clarifed. Recent studies on the structure and function of the plasma kininogens, their interaction with cells of the intravascular compartment, and clinical investigations on contact system activation have refocused the physiologic importance of these proteins to kinin delivery for the maintance of vasodilatory tone. Kininogen expression on platelets slows the rate of kinin liberation, and kinins upregulate kininogen expression on endothelial cells. Regulation of kinin delivery by influencing kininogen expression may provide for new agents to manipulate blood pressure. (Trends Cardiovasc Med 1992;2:108-114)

The particular physiologic role of the proteins of the contact system of plasma proteolysis has been elusive. Activation of the proteases of this system has been reported to initiate intrinsic coagulation,

Alvin H. Schmaier is at the Division of Hematology and Oncology, Department of Internal Medicine, Simpson Memorial Research Institute, University of Michigan, Ann Arbor, MI 48109-0724, USA. activate the fibrinolytic system, and influence blood pressure. Although much work has been performed over the last 15 years, little progress has been made in understanding this system in hemostasis and fibrinolysis. Deficiencies of the zymogens of this system, factor XII (Hageman factor) and prekallikrein (Fletcher factor), or their cofactor/substrate, highmolecular-weight kininogen (Fitzgerald or Williams factor) give rise to striking abnormal procoagulant states in vitro but no corresponding clinical bleeding states. The absence of any hemostatic defect suggests no direct role for these proteins in hemostasis. This interpretation is supported by recent work showing that in the presence of negatively charged surfaces, such as sulfatides and dextran sulfate, thrombin is a better activator of factor XI, the first committed protein of the hemostatic system, than activated forms of factor XII (Naito and Fujikawa 1991; Gailani and Broze 1991). Similarly, the role of this system in fibrinolysis needs better definition. Activated forms of factor XII, prekallikrein, and factor XI have all been shown to activate plasminogen to plasmin, but this entire system is at best $1 / 10,000$ as potent as the endogenous tissue and urokinase plasminogen activator systems. Alternatively, desamino D-arginine vasopressin-induced plasminogen-activating activity is partially dependent on the contact system since it is impaired in factor-XII-deficient individuals (Levi et al. 1991).

Even though little progress has been made in understanding the contact system's role in hemostasis and fibrinolysis, significant progress has been made in understanding the structure and function of high-molecular-weight kininogen (HK), the main cofactor and substrate of this system. Investigations on $\mathrm{HK}$ and the other plasma kininogen, low-molecular-weight kininogen (LK), indicate roles for these proteins in local blood pressure regulation and possibly fibrinolysis. The first recognized function of the plasma kininogens was to serve as the parent protein for the potent vasoactive peptide, bradykinin (BK). Recent laboratory studies on the interaction of the kininogens with cells in the vascular compartment and clinical investigations have allowed for a reorientation of interest back to the kinin delivery function of the kininogens and, in turn, a refocusing on the significance of the proteases of this system that serve as kininogenases. This review summarizes recent information on the kininogens' structure and function and their interaction with cells. This information will suggest an important physiologic activity for these proteins and their regulating proteases in the maintenance and modulation of blood pressure homeostasis. 


\section{- Structure and Function of the Kininogens}

Both kininogens, HK and LK, are produced by a single gene (Takagaki et al. 1985) that maps to chromosome 3 (Fong et al. 1991). This single gene of 11 exons and 27 kilobases $(\mathrm{kb})$ produces a unique mRNA for each kininogen by alternative splicing (Kitamura et al. 1985). HK and LK share the coding region of the first nine exons and a part of exon 10 containing the bradykinin sequence and the first 12 amino acids after the carboxyterminal portion of bradykinin. Exon 11 codes for the unique 4-kD light chain of LK. The complete exon 10 contains the full coding region for the unique $56-\mathrm{kD}$ light chain of HK. By alternative RNA processing events, $\mathrm{HK}$ is produced from exon 10. In the rat kininogen gene, a novel mechanism occurs for alternative RNA processing (Kakizuka et al. 1990). Splicing efficiency is controlled by the interaction of $\mathrm{U} 1$ small nuclear ribonucleoproteins and the U1 snRNA-complementary repetitive sequences of the kininogen pre-mRNA. The mRNA for LK and $\mathrm{HK}$ are 1.7 and $3.5 \mathrm{~kb}$, respectively.

The two mRNAs of the kininogens code for two separate proteins. $\mathrm{LK}$ is a $66-\mathrm{kD} \beta$-globulin with a plasma concentration of $160 \mu \mathrm{g} / \mathrm{mL}$ (Schmaier et al. $1986 \mathrm{a}) . \mathrm{HK}$ is a $120-\mathrm{kD} \alpha$-globulin with a plasma concentration of $80 \mu \mathrm{g} / \mathrm{mL}$ (Schmaier et al. 1983). Both kininogens have a common $64-\mathrm{kD}$ so-called heavy chain, the $B K$ sequence, and the 12 amino acids after the carboxy terminus of BK. The common heavy chain of both kininogens consists of three domains (Salvesen et al. 1986). Domain 1 of the heavy chain has a low-affinity calcium-binding site whose function has yet to be characterized (Ishiguro et al. 1987). Domains 2 and 3 contain the highly conserved amino acid sequence QVVAG found in cysteine protease inhibitors. Both $\mathrm{LK}$ and $\mathrm{HK}$ are potent, tight-binding, reversible cysteine protease inhibitors with $\mathrm{K}_{\mathrm{i}}$ s of 2 and 0.5 $\mathrm{nM}$, respectively, against human platelet calpain (Bradford et al. 1990). Until its cloning, LK was also known as $\alpha_{1}$ cysteine protease inhibitor. Although both domains 2 and 3 are inhibitors of most cysteine proteases, domain 2 of the kininogens contains the inhibitory area for calpains, calcium-activated cysteine proteases (Schmaier et al. 1987). Since most cysteine proteases are intracellular,

a function of the kininogens may be to act as a cell membrane regulator of these proteins when they become externalized upon cell activation (Schmaier et al. 1990).

Both kininogens are parent proteins for BK. LK is a better substrate for tissue kallikreins to liberate lys-BK; $\mathrm{HK}$ is a better substrate for plasma kallikrein to liberate BK. Elastase treatment of LK facilitates the liberation of BK and met-lysBK by plasma kallikrein (Sato and Nagasawa 1988). Alternatively, elastase proteolyses the light chain of HK and destroys its procoagulant activity (Kleniewski and Donaldson 1988). Likewise, human cathepsin $D$ inactivates the cysteine protease inhibitory activity of the kininogens by proteolyzing domain 3 (Lenarcic et al. 1991). A wide range of bacterial proteases are also able to liber-

\section{A WIDE RANGE OF BACTERIAL PROTEASES ARE ABLE TO LIBERATE KININS, SUGGESTING THAT THE HYPOTENSION OFTEN SEEN IN SEPSIS MAY BE DUE TO A DIRECT EFFECT OF THE INFECTING ORGANISM'S PROTEASES IN LIBERATING KININS.}

ate kinins, suggesting that the hypotension often seen in sepsis may be due to a direct effect of the infecting organism's proteases in liberating kinins (Akhteruzzaman et al. 1989).

The 56-kD light chain of HK has the unique property to serve as a cofactor in the activation of factor XII, prekallikrein, and factor XI. The procofactor activity of $\mathrm{HK}$ results from the functional activity of the two domains that compose the light chain of HK. Domain 5 is a histidineand glycine-rich region that has the ability to bind to anionic surfaces. This region contains a zinc-binding site of high affinity such that $\mathrm{HK}$ can be purified on zinc chelate chromatography (Retzio et al. 1987). The zinc-binding region on HK's domain 5 can also function to decrease the heparin-enhancing inhibitory effect of antithrombin III on $\alpha$-thrombin (Bjork 1989). Domain 6 of the light chain of HK contains the factor-XI-and prekallikreinbinding sites (Tait and Fujikawa 1986;
Vogel et al. 1990). The prekallikrein- and factor-XI-binding site is contained within a 31-residue peptide that contains predominantly $\beta$-turn elements (Scarsdale and Harris 1990). The procoagulant activity of $\mathrm{HK}$ depends upon intact functioning of these two domains of the protein. Firstly, a region on domain 5 of HK must bind to anionic surfaces; secondly, another region on domain 6 of HK must form complexes with prekallikrein and factor XI. Blockage of either interaction with monoclonal antibodies directed to these regions will inhibit HK's procoagulant activity (Schmaier et al. 1987; Reddigari and Kaplan 1989).

\section{- The Interaction of the Kininogens with Cells of the Vascular Compartment}

HK has been found to be contained in platelet $\alpha$-granules, and $<8 \%$ of total platelet $\mathrm{HK}$ is plasma $\mathrm{HK}$ tightly bound and nonexchangeable with the platelet membrane (Schmaier et al. 1983 and 1986b). Upon platelet activation, $40 \%$ of the total amount of platelet HK is secreted and another $40 \%$ of the total amount of platelet HK becomes expressed upon the activated platelet membrane (Figure 1). The total platelet contribution of HK to plasma $\mathrm{HK}$ is only $0.23 \%$. Since platelets secrete their granule content by exocytosis, however, the local concentration of $\mathrm{HK}$ on or about the activated platelet surface may exceed ten times the plasma concentration of this protein. Unstimulated and activated platelets have unoccupied binding sites for HK (Gustafson et al. 1986; Greengard and Griffin 1984). The affinity of the kininogens to bind to unstimulated and activated platelets is the same. Human platelets also have high-affinity binding sites for low-molecular-weight kininogen (Meloni and Schmaier 1991). LK and $\mathrm{HK}$ are mutually competitive in binding to the unstimulated platelet surface. Both HK and LK bind to the platelet surface as intact proteins.

Human granulocytes contain HK and have high-affinity, unoccupied binding sites for HK (Gustafson et al. 1989a). HK serves as a noncompetitive inhibitor of fibrinogen binding to granulocytes (Gustafson et al. 1989b). OKM1, which is a monoclonal antibody to the leukocyte integrin CD 11b/CD 18 (MAC1), blocks fibrinogen binding to granulocytes, but 


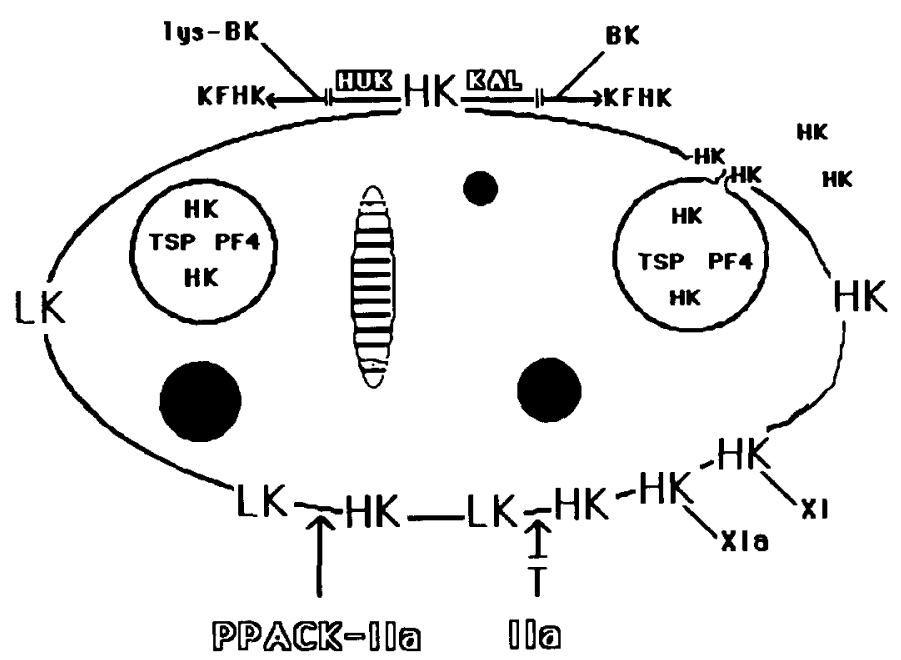

Figure 1. Kininogen-platelet interactions. $H K$, high-molecular-weight kininogen; $L K$, low-molecularweight kininogen; $B K$, bradykinin; lys-BK, lys-bradykinin; $H U K$, human urinary kallikrein; $K A L$, plasma kallikrein; $K F H K$, kinin-free high-molecular-weight kininogen; TSP, thrombospondin; PF4, platelet-factor 4; IIa, $\alpha$-thrombin; XI, factor XI; XIa, activated factor XI; and PPACK-IIa, D-phenylalanyl-prolyl-arginine chloromethyl ketone-treated $\alpha$-thrombin. HK is contained in platelet $\alpha$-granules. Upon stimulation of platelets by any agonist, platelet HK is secreted from platelet $\alpha$-granules into the suspension media. In addition to secretion of platelet $\mathrm{HK}$, a portion of equal amount to secreted platelet $\mathrm{HK}$ is expressed upon the activated platelet membrane. The unstimulated platelet also contains unoccupied binding sites for HK or LK. Platelet-bound HK serves as a binding site for factors XI and XIa. Platelet-bound HK or LK can block $\alpha$-thrombin, but not PPACK-thrombin, from binding to its high-affinity site. Plateletbound HK and LK are substrates for plasma and tissue kallikrein to release bradykinin or lys-bradykinin, respectively, and leave kinin-free HK or LK, respectively, bound to the platelet surface.

does not block HK binding (Figure 2). Granulocyte-bound HK is proteolyzed by elastase. Human umbilical vein endothelial cells in culture are able to adsorb HK from their media and are also able to synthesize the protein from their consti-

tutively expressed pool of HK mRNA (Van Iwaarden et al. 1988a; Schmaier et al. 1988). Human umbilical vein endothelial cells also contain high-affinity binding sites for HK (Van Iwaarden et al. 1988b; Schmaier et al. 1988) and LK

Figure 2. High-molecular-weight kininogen-granulocyte interactions. $F b$, fibrinogen; and elastase, human neutrophil elastase. All other abbreviations are defined in the Figure 1 legend. $\mathrm{HK}$ is contained in total lysates of well-washed granulocytes. It can also bind to unoccupied binding sites on the granulocyte surfacc. Membrane-expressed HK could serve as a kallikrein-binding site. Membrane-bound $\mathrm{HK}$ serves as a noncompetitive inhibitor of fibrinogen binding to granulocytes. OKM1 blocks fibrinogen binding to granulocytes, but does not block HK binding to granulocytes. Granulocyte HK participates in allowing the full extent of its elastase secretion induced by plasma kallikrein.

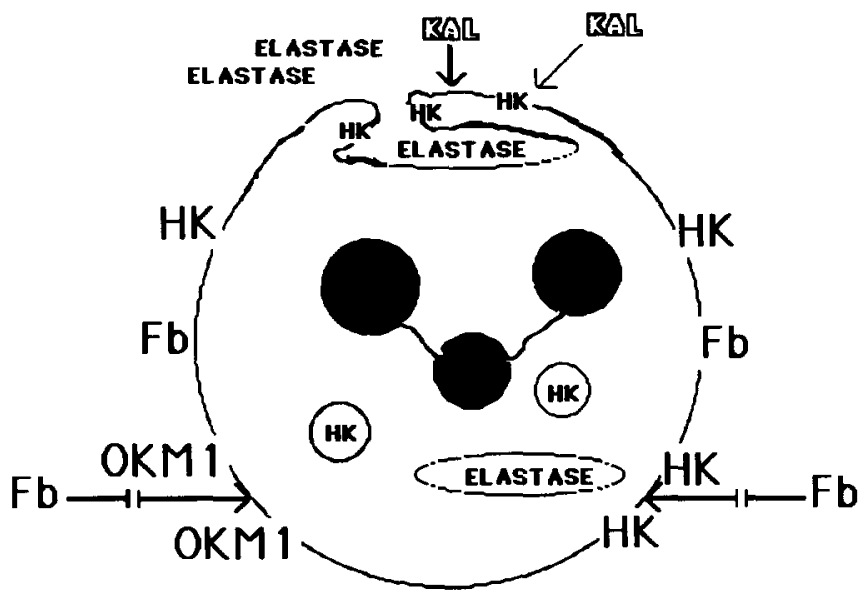

(Zini et al. 1991). Bradykinin through protein kinase $C$ is able to upregulate HK- and LK-binding sites on endothelial cells. Endothelial cells may have unique binding sites for HK's light chain and kininogen's heavy chain since phorbol esters alone only increase the former and calcium ion and phorbol esters only upregulate the latter (Zini et al. 1991). HK binds to the endothelial cell surface as an uncleaved protein. Endothelial cell membrane-bound HK has the potential to deliver bradykinin, which can stimulate the release of a number of metabolic products (Figure 3). HK binds to platelets, granulocytes, and endothelial cells with similar affinity (Table 1). Since the affinity of $\mathrm{HK}$ binding to cells in the intravascular compartment is $10-52 \mathrm{nM}$, and the plasma concentration of $\mathrm{HK}$ is $670 \mathrm{nM}$, we can postulate that all kininogen-binding sites in the intravascular compartment are saturated in vivo. The number of binding sites for the kininogens on cells in the intravascular compartment varies as to the cell. Platelets have $\sim 1000$ binding sites/cell; granulocytes, 50,000/cell; and endothelial cells $\sim 1,000,000$ sites/cell (Table 1). However, if one calculates the density of distribution of HK-binding sites per unit of surface area, each of these cells found within the intravascular compartment has about the same density of distribution of kininogen-binding sites per unit of surface area. This finding suggests that the availability of kininogen substrate for kinin delivery is equally distributed on platelets, granulocytes, and endothelial cells in the intravascular compartment.

\section{- Domains of the Plasma Kininogens That Participate in Cell Membrane Binding}

It has been a common understanding to investigators in the field that since $\mathrm{HK}$ contains a region on its light chain that binds to anionic surfaces, any interaction of HK with cells, a physiologic surface, must also be proceeding through its $56-\mathrm{kD}$ light chain. However, the finding that LK specifically binds to platelets and functions as a mutual competitor of HK binding to platelets suggests that there must be a region of the heavy chain of the kininogens that contains a cell-binding domain (Table 1) (Meloni and Schmaier 1991). Accord- 
ingly, the isolated heavy chain of $\mathrm{HK}$ inhibits HK binding to platelets (Meloni et al. 1992). However, LK or the purified light chain of HK are not mutual competitors of the other binding to platelets. Monoclonal antibodies directed to domain 3 (D3) on kininogens' heavy chain inhibited [ $\left.{ }^{125} \mathrm{I}\right] \mathrm{HK}$ from binding to platelets (Jiang et al. 1992). Further, isolated D3 from the heavy chain of the kininogens was found to bind specifically to the unstimulated platelet surface and human umbilical vein endothelial cells. D3 binding to platelets is reversible and saturable (Table 1). D3 can function as a competitor of either HK or LK binding to platelets. Unlike HK and LK, which both require zinc ion for binding, D3 does not need zinc to bind to platelets. Since both $\mathrm{HK}$ and LK require zinc ion in order to bind to platelets, the role of this divalent cation must be on the expression of the putative kininogen receptor(s) on platelets, similar to the role of zinc ion for conformational changes of the human growth hormone receptor for growth hormone binding. D3 being a smaller protein may be able to insert into its site without the receptor having the necessary conformational changes for binding of the larger proteins.

Although D3 on the heavy chain of the plasma kininogens contains a cellbinding site, it is not the exclusive cell-binding domain for $\mathrm{HK}$. The purified $56-\mathrm{kD}$ light chain of $\mathrm{HK}$ has the ability to inhibit $\left[{ }^{125} \mathrm{I}\right] \mathrm{HK}$, but not $\left[{ }^{125} \mathrm{I}\right] \mathrm{LK}$, from binding to platelets. The $\left[{ }^{125} \mathrm{I}\right] 56$ $\mathrm{kD}$ light chain of HK can directly bind to the platelet surface (Meloni et al. 1992). The [125I] light chain of HK binding to platelets is specific because it is blocked by the unlabeled light chain, HK, EDTA, or no zinc, but it is not inhibited by LK or unrelated plasma proteins. These data indicate that two domains on HK participate in platelet binding: one on its heavy chain and another on its light chain (Figure 4).

\section{- Significance of the Cellular Expression of the Plasma Kininogens}

Kininogens on platelets and granulocytes have been shown to have a number of functions. Platelet-bound $\mathrm{HK}$ serves as a binding site for factor XI/XIa (Greengard et al. 1986; Sinha et al. 1984). The function of platelet-bound FXIXXIa has

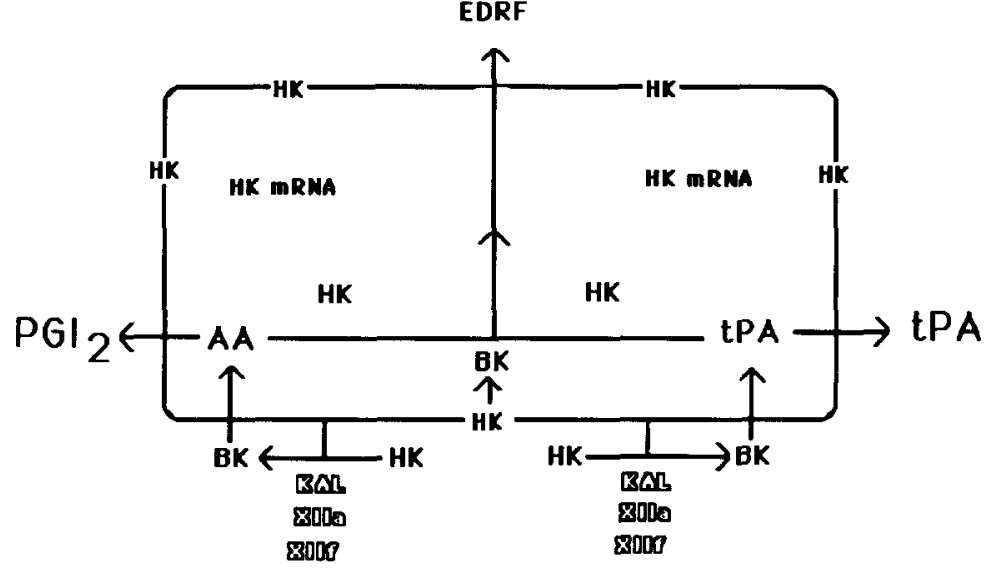

Figure 3. High-molecular-weight kininogen-endothelial cell interactions. EDRF, endothelial-cellderived relaxing factor or nitric oxide; $t P A$, tissue plasminogen activator; $P G I_{2}$, prostacyclin; $X I I a$, activated factor XII; and $X I I_{f}$, Hageman factor fragment. All other abbreviations are defined in the Figure 1 legend. Human umbilical vein endothelial cells grown in culture contain unoccupied binding sites for HK. Thesc cndothclial cclls contain HK antigen and have a high constitutive expression of HK mRNA. Theoretically, bradykinin liberated from soluble or cell-bound kininogen can stimulate these prostaglandin synthesis systems to stimulate prostacyclin production. Bradykinin from kininogen can also stimulate EDRF release and tPA production. yet to be clarified, since cell-bound factor XIa is not a better activator of factor IX than unbound factor XIa. HK serves as a noncompetitive inhibitor of the cytoadhesion function of fibrinogen on granulocytes and activated platelets, but not on unstimulated platelets (Gustafson et al. 1989b). The relative importance of this effect needs to be clarified, but it could be important in modifying fibrinogen or other adhesive glycoproteins' interactions with cells. Granulocyte HK also serves as a cofactor for the full expression of kallikrein-induced elastase secretion, probably by serving as an additional receptor for kallikrein (Gustafson et al. 1989a). Platelet-bound HK or LK could serve as a membranelocalized inhibitor of calpain when calpain is expressed upon the activated Puri et al. 1991). This mechanism could be important in limiting the extent of glycocalicin liberation from glycoprotein Ib and in modulating the exposure of the fibrinogen receptor by externalized calpain.

Platelet membrane-expressed kininogens also have the ability to inhibit thrombin-induced platelet aggregation and secretion (Meloni and Schmaier 1991). Initially, this effect was thought to be due to the ability of membrane-bound kininogens to inhibit externalized plateplatelet surface (Schmaier et al. 1990;

Table 1. Kininogen expression on cells

\begin{tabular}{lcc}
\hline Cell type & $K_{\text {, or } K_{d}{ }^{a}(n M)}$ & No. of siles \\
\hline Platelets & & \\
$\quad\left[{ }^{125}\right]$ HK & $15 \pm 4^{c}$ & $911 \pm 239$ \\
$\quad\left[{ }^{125} \mathrm{I}\right] \mathrm{LK}$ & $27 \pm 2$ & $647 \pm 147$ \\
$\quad\left[{ }^{125} \mathrm{I}\right] \mathrm{D} 3$ & $39 \pm 8$ & $1227 \pm 404$ \\
Granulocytes & & \\
$\quad\left[{ }^{125} \mathrm{I}\right] \mathrm{HK}$ & $10 \pm 1.3$ & $4.8 \times 10^{4}$ \\
Endothelial cells & & \\
$\quad\left[{ }^{125}\right]$ HK & $52 \pm 13$ & $9.3 \times 10^{5}$ \\
$\quad\left[{ }^{125} \mathrm{I}\right] \mathrm{LK}$ & $43 \pm 8$ & $9.7 \times 10^{5}$ \\
\hline
\end{tabular}

"The numbers presented represent direct binding to the radioligand to the indicated cell.

${ }^{b}$ The abbreviations used in this column are as follows: $H K$, high-molecular-weight kininogen; $L K$, low-molecular-weight kininogen; and $D 3$, domain 3 of the heavy chain of the plasma kininogens.

$c$ Values represent \pm the standard deviation. 


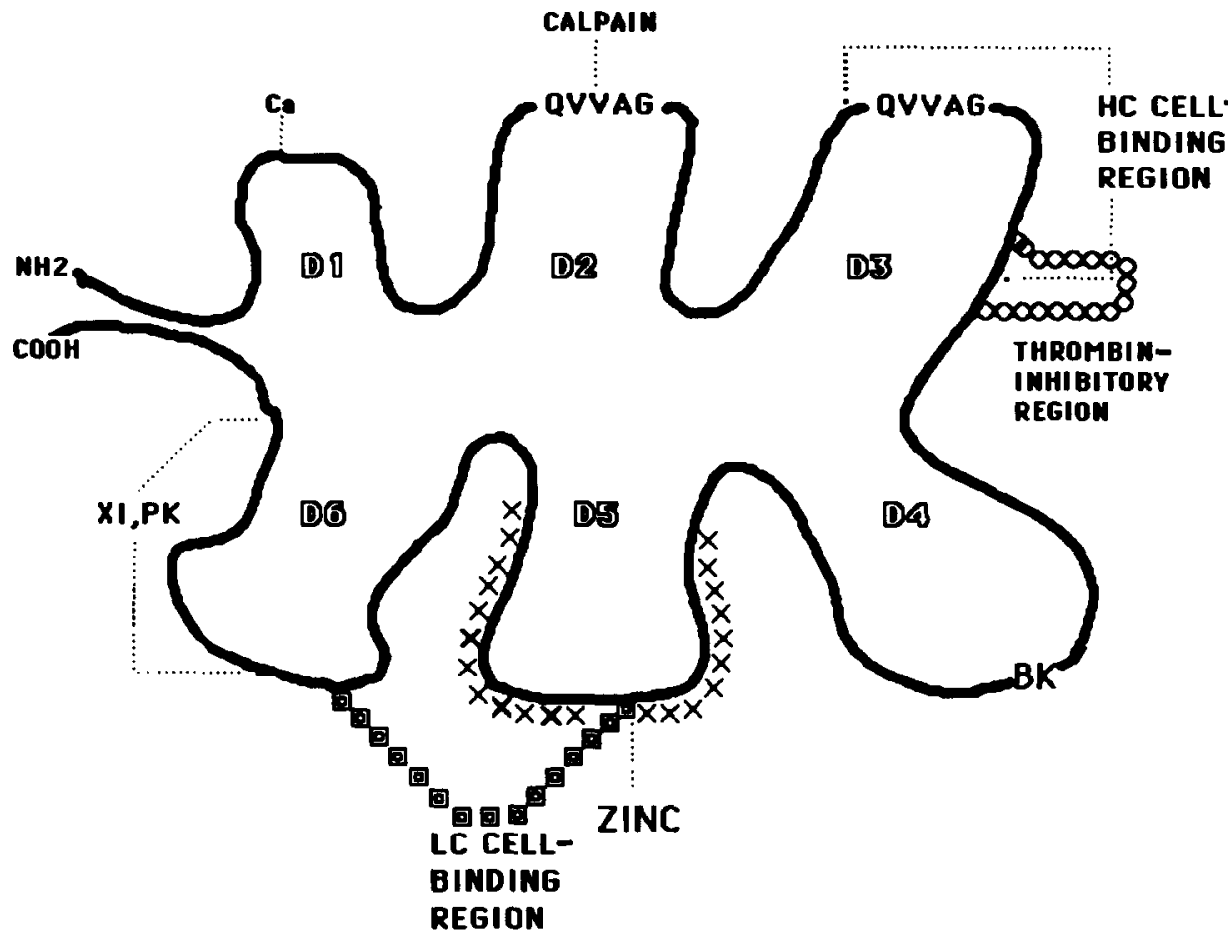

Figure 4. Structure and function of high-molecular-weight kininogen. $H C$, heavy chain of the kininogens; and $L C$, light chain of HK. All other abbreviations are explained in the Figure 1 legend. High-molecular-weight kininogen is divided into six domains. Domains 1-3 (DI-D3) are the so-called heavy chain of the plasma kininogens. Domain 1 contains a low-affinity calcium-binding site. Both domains 2 and 3 contain a highly conserved amino acid sequence, QVVAG, which is contained in most cysteine protease inhibitors. Uniquely, domain 2 inhibits the calcium-activated cysteine protease, calpain. Domain 3 has been found also to contain a cell-binding region and another epitope that contains a region inhibitory to thrombin binding to platelets. Domain $4(D 4)$ is the bradykinin sequence. Domain $5(D 5)$ is an HG-rich region that binds zinc and binds to anionic surfaces. Domain $6(D 6)$ contains the prekallikrein- and factor-XI-binding region. There is another cell-binding region on the light chain of $\mathrm{HK}$, but it is unclear as of yet as to whether it is contained on domain 5 or domain 6 of the kininogens.

let calpain. However, the finding that both HK and LK inhibited platelet secretion independent of platelet aggregation indicated that the kininogens influenced the interaction of thrombin with platelets in a more fundamental manner. Both HK and LK were found to be noncompetitive inhibitors of $\alpha$-thrombin binding to its receptor. The kininogens do not complex with $\alpha$-thrombin, or inhibit the proteolytic activity of thrombin, or inhibit an amino-terminus peptide of the thrombin receptor from activating platelets (Meloni and Schmaier 1991; Jiang et al. 1992). Further, the kininogens do not bind to thrombin's binding site on platelets because they do not inhibit D-phenylalanyl-prolyl-arginine chloromethyl ketone-treated $\alpha$-thrombin from binding to platelets. D3 of the kininogens' heavy chain functions as a thrombin inhibitor similar to the intact significance of this finding is discussed in the following sections.

\section{- Physiologic Importance of Activation of the Contact System of Plasma Proteolysis}

It has been argued that the importance of the plasma LK and HK cannot simply reside in $1.6 \%$ and $0.8 \%$, respectively, of their molecular mass. However, it is equally cogent to argue that the design of these proteins is exclusively for kinin delivery to areas where it will be most effective. This latter hypothesis is supported by a wealth of clinical data ascertaining the significance of plasma contact system activation. Factor XII activation during the preparation of a plasma protein fraction resulted in a product that induced hypotension upon infusion (Alving et al. 1978). Although activation of the contact system is purported to activate the coagulation system, a study of adult respiratory distress syndrome induced by either sepsis or trauma showed profound activation of the contact system with little activation of prothrombin (Carvalho et al. 1988). Alternatively, early Rocky Mountain spotted fever, an archetypal endothelial cell injury disorder, was associated with profound thrombin formation and platelet activation with little contact system activation (Rao et al. 1988). These two investigations indicate that activation of the contact system is independent of activation of the hemostatic system and vice versa. This interpretation is supported by the clarification of the importance of the tissue factor-factor VII system in activating factor $\mathrm{X}$ directly or indirectly through factor IX activation. Alternatively, in patients with sepsis, the degree of activation of the contact system correlated with the observed degree of hypotension (Kaufman et al. 1991). These studies suggest that activation of the contact system is mostly associated with hypotension and vascular instability. Formation of the plasma enzymes of the contact system results in the liberation of bradykinin from its substrate kininogens. The multidomain nature of the kininogens can be interpreted as highly refined bradykinin delivery systems. HK can bind to cells by two portions to bring its kininogenases kallikrein and factor XIa to cell surfaces to liberate externalized bradykinin from its 
parent molccule. Its cysteine-proteaseinhibitory domain could prevent tissue cysteine proteases from totally lysing the protein (Schmaier et al. 1986b). The thrombin-inhibitory domain on kininogens could serve to limit thrombin binding to cells to decrease thrombin's ability to activate factor $\mathrm{XI}$ and cleave $\mathrm{HK}$ to possibly liberate more kinin (Naito and Fujikawa 1991; Gailani and Broze 1991).

\section{- Role of the Kininogens in the Modulation of Blood Pressure}

Bradykinin has profound effects on the vascular endothelium. It stimulates inositol phosphate production in these cells to induce prostacyclin synthesis and superoxide formation (Hong 1980; Lambert et al. 1986; Holland et al. 1990). It also stimulates the release of tissue plasminogen activator in vivo (Smith et al. 1983) and nitric oxide or endothelium-derived relaxing factor (EDRF) (Palmer et al. 1987). Clinical states associated with bradykinin elevation, such as sepsis, are characterized by hypotension. Agents such as angiotensin-converting enzyme (ACE) inhibitors that inhibit one of the enzymes (kininase II or ACE) that proteolyze bradykinin are potent afterload rcducers and antihypertensives. It is reasonable to hypothesize that any agent that modifies delivery of bradykinin to the endothelium will modify its influence on vascular tissue. Since the kininogens, $\mathrm{HK}$ and LK, are the parent molecules of bradykinin or its derivatives, any modification of their expression on cells in the intravascular compartment should alter the availability of the substrate for kinin formation. Thus, blocking kininogen binding to cells by a peptide directed to its cellbinding domain could inlluence the degree of cell-bound kininogen. Similarly, regulating the putative receptor(s) for the kininogens on cells in the intravascular compartment could modulate the amount of bound kininogen. Since a number of kininases in addition to ACE are transmembrane and plasma proteins, the notion has arisen that physiologically influential bradykinin must be that which arises in a protected milieu. Although our studies with platelets indicate that plateletbound kininogen has delayed bradyki- nin liberation in comparison to soluble kininogen, it has yet to be determined whether physiologic, vasoregulatory bradykinin is derived from cellbound or soluble kininogen. Ascertaining the locus of physiologic bradykinin liberation will be a key step in understanding the role of this peptide in the autocrine regulation of vascular tone. Modulating the cell binding of kininogens by blocking its receptor or downregulating the receptor(s)' expression could be a new means to regulate blood pressure homeostasis.

\section{- Acknowledgments}

The author thanks Drs. Ellen Gustafson, Frank Meloni, and Yongping Jiang for their contributions toward the development of these ideas. This project was supported in part by grant 6437 from the March of Dimes Birth Defect Foundation, grants-in-aid 891247 from the $\mathrm{Na}$ tional American Heart Association and the Southeastern Pennsylvania Affiliate of the American Heart Association, a grant from the W.W. Smith Charitable Trust, and HL 35553. The author is a recipient of a Research Career Development Award HL01615 from the National Institutes of Health.

\section{References}

Akhteruzzaman M, Yamamoto T, Akaike T, Miyoshi S, Maeda H: 1989. Activation of Hageman factor and prekallikrein and generation of kinin by various microbial proteinases. J Biol Chem 264:10,589-10,594.

Alving BM, Hojima Y, Pisano JJ, Mason BL, et al.: 1978. Hypotension associated with prekallikrein activator (Hageman-factor fragments) in plasma protein fraction. $\mathrm{N}$ Engl J Med 299:66-70.

Bjork I, Olsen ST, Sheffer RG, Shore JD: 1989. Binding of heparin to human high-molecularweight kininogen. Biochemistry 28:12131221 .

Bradford H, Schmaier AH, Colman RW: 1990. Kinetics of inhibition of platelet calpain II by human kininogens. Biochem J 270:83-90.

Carvalho AC, DeMarinis S, Scott CF, Silver LD, Schmaier AH, Colman RW: 1988. Activation of the contact system of plasma proteolysis in the adult respiratory distress syndrome. J Lab Clin Med 112:270-277.

Fong D, Smith DI, Hsieh W-T: 1991. The human kininogen gene (KNG) mapped to chromosome 3q26-qter by analysis of somatic cell hybrids using the polymerase chain reaction. Hum Genet 87:189-192.

Gailani D, Broze GJ Jr: 1991. Factor XI activation in a revised model of blood coagulation. Science 253:909-912.

Greengard IS, Griffin JH: 1984. Receptors for high-molecular-weight kininogen on stimulated washed human platelets. Biochemistry 23:6863-6869.

Greengard JS, Heeb MJ, Ersdal E, Walsh PN, Griffin JH: 1986. Binding of coagulation factor XI to washed human platelets. Biochemistry 25:3884-3890.

Gustafson, EJ, Schutsky D, Knight LC, Schmaier AH: 1986. High molecular weight kininogen binds to unstimulated platelets. J Clin Invest 78:310-318.

Gustafson EJ, Schmaier AH, Wachtfogel YT, Kaufman N, Kucich U, Colman RW: 1989a. Human neutrophils contain and bind highmolecular-weight kininogen. J Clin Invest $84: 28-35$

Gustafson EJ, Lukasiewicz H, Wachtfogel YT, Norton KJ, et al.: 1989b. High molecular weight kininogen inhibits fibrinogen binding to cytoadhesions of neutrophils and platelets. J Cell Biol 109:377-387.

Holland JA, Pritchard KA, Pappolla MA, Wolin MS, Rogers NJ, Stemerman MB: 1990. Bradykinin induces superoxide anion release from human endothelial cells. J Cell Physiol 143:21-25.

Hong SL: 1980. Effect of bradykinin and thrombin on prostacyclin synthesis in endothelial cells from calf and pig aorta and human umbilical cord vein. Thromb Res 18:787-795.

Ishiguro H, Higashiyama S, Ohkubo L, Sasaki M: 1987. Mapping of functional domains of human high molecular weight and low molecular weight kininogens using murine monoclonal antibodies. Biochemistry 26:7021-7029.

Jiang Y-P, Muller-Esterl W, Schmaier AH: 1992. Domain 3 of kininogen contains a cell binding site and a site that modifies thrombin activation of platelets. J Biol Chem 267:3712-3717.

Kakizuka A, Ingi T, Murai T, Nakanishi S: 1990. A set of U1 snRNA-complementary sequences involved in governing alternative RNA splicing of the kininogen genes. $\mathrm{J}$ Biol Chem 265:10,102-10,108.

Kaufman N, Page J, Pixley RA, Schein R, Schmaier AH, Colman RW: 1991. $\alpha_{2^{-}}$ Macroglobulin-kallikrein complexes detect contact system activation in hereditary angioedema and human sepsis. Blood 77:2660-2667.

Kitamura N, Kitagawa H, Fukushima D, Takagaki Y, Miyata T, Nakanishi S: 1985. Structural organization of the human kininogen gene and a model for its evolution. J Biol Chem 260:8610-8617. 
Kleniewski J, Donaldson V: 1988. Granulocyte elastase cleaves human high-molecularweight kininogen and destroys its clotpromoting activity. J Exp Med 167:18951907.

Lambert TL, Kent RS, Whorton AR: 1986. Bradykinin stimulation of inositol polyphosphate production in procine aortic endothelial cells. J Biol Chem 261:15,288$15,293$.

Lenarcic B, Krasovec M, Ritonja A, Olafsson I, Turk V: 1991. Inactivation of human cystatin $C$ and kininogen by human cathepsin D. FEBS Lett 280:211-215.

Levi M, Hack CE, de Boer JP, Brandjes DPM, Buller HR, ten Cate JW: 1991. Reduction of contact activation related fibrinolytic activity in factor XII deficient patients. J Clin Invest 88:1155-1160.

Meloni FJ, Schmaier AH: 1991. Low molecular weight kininogen binds to platelets to modulate thrombin-induced platelet activation. J Biol Chem 266:6786-6794.

Meloni FJ, Gustafson EJ, Schmaier AH: 1992. High molecular weight kininogen binds to platelets by its heavy and light chains and when bound has altered susceptibility to kallikrein cleavage. Blood 79:1233-1244.

Naito K, Fujikawa K: 1991. Activation of human blood coagulation factor XI independent of factor XII. J Biol Chem 266:73537358.

Palmer RMJ, Ferrige AG, Moncada S: 1987. Nitric oxide release accounts for the biologic activity of endothelium-derived relaxing factor. Nature 327:524-526.

Puri RN, Zhou F, Hu C-J, Colman RF, Colman RW: 1991. High molecular weight kininogen inhibits thrombin-induced platelet aggregation and cleavage of aggregin by inhibiting binding of thrombin to platelets. Blood 77:500-507.

Rao AK, Schapira M, Clements ML, Niewiarowski S, et al.: 1988. A prospective study of platelets and plasma proteolytic systems during the early stages of Rocky Mountain spotted fever. N Engl J Med 318:1021-1028.

Reddigari S, Kaplan AP: 1989. Monoclonal antibody to human high-molecular-weight kininogen recognizes its prekallikrein binding site and inhibits its coagulant activity. Blood 74:695-702.

Retzio AD, Rosenfeld R, Schiffman S: 1987. Effects of chemical modifications on the surface- and protein-binding properties of the light chain of human high-molecularweight kininogen. J Biol Chem 262:30743081 .

Salvesen G, Parkes C, Abrahamson M, Grubb A, Barrett AJ: 1986. Human low-molecularweight kininogen contains three copies of a cystatin sequence that are divergent in structure and in inhibitory activity for cysteine proteases. Biochem J 234:429-434.

Sato F, Nagasawa S: 1988. Mechanism of kinin release from human low-molecularmass-kininogen by synergistic action of human plasma kallikrein and leukocyte elastase. Biol Chem Hoppe Seyler 369:10091017.

Scarsdale JN, Harris RB: 1990. Solution phase conformation studies of the prekallikrein binding domain of high-molecularweight kininogen. J Protein Chem 9:647659.

Schmaier AH, Zuckerberg A, Silverman C, Kuchibhotla J, Tuszynski GP, Colman RW: 1983. High-molecular weight kininogen: a secreted platelet protein. J Clin Invest 71:1477-1489.

Schmaier AH, Bradford H, Silver LD, Farber A, et al.: 1986a. High molecular weight kininogen is an inhibitor of platelet calpain. $\mathrm{J}$ Clin Invest 77:1565-1573.

Schmaier AH, Smith PM, Purdon AD, White JG, Colman RW: 1986b. High molecular weight kininogen: localization in the unstimulated and activated platelet and activation by a platelet calpain(s). Blood 67:119-130.

Schmaier AH, Schutsky D, Farber A, Silver LD, Bradford HN, Colman RW: 1987. Determination of the bifunctional properties of high-molecular-weight kininogen by studies with monoclonal antibodies directed to each of its chains. J Biol Chem 262:14051411.

Schmaier AH, Kuo A, Lundberg D, Murray S, Cines DB: 1988 . The expression of highmolecular-weight kininogen on human umbilical vein endothelial cells. J Biol Chem 263:16,327-16,333.

Schmaier AH, Bradford HN, Lundberg D, Farber A, Colman RW: 1990. Membrane expression of platelet calpain. Blood 75:1273 1281.

Sinha D, Seaman FS, Koshy A, Knight LC, Walsh PN: 1984. Blood coagulation factor XIa binds specifically to a site on activated human platelets distinct from that for factor XI. J Clin Invest 73:1550-1556.

Smith D, Gilbert M, Owen WG: 1983. Tissue plasminogen activator release in vivo in response to vasoactive agents. Blood 66:835-839.

Tait JF, Fujikawa K: 1986. Identification of the binding site for plasma prekallikrein in human high-molecular-weight kininogen. J Biol Chem 261:15,396-15,401.

Takagaki Y, Kitamura N, Nakanishi S: 1985. Cloning and sequence analysis of CDNAs for human high-molecular-weight and lowmolecular-weight prekininogens. J Biol Chem 260:8601-8609.

Van Iwaarden F, de Groot PG, Sixma JJ, Berrettini M, Bouma BN: 1988a. High molecular weight kininogen is present in cultured human endothelial cells: localization, isolation, and characterization. Blood $71: 1268-1276$

Van Iwaarden F, de Groot PG, Bouma BN: $1988 \mathrm{~b}$. The binding of high-molecularweight kininogen to cultured human endothelial cells. J Biol Chem 263:4698-4703.

Vogel R, Kaufmann J, Chung DW, Kellermann J, Muller-Esterl W: 1990. Mapping of the prekallikrein-binding site of human $\mathrm{H}$-kininogen by ligand screening of $\lambda \mathrm{gt} 11$ expression libraries. J Biol Chem 265:12,494 12,502 .

Zini JM, Schmaier AH, Cines DB: 1991. Bradykinin stimulates the binding of its precursors, high and low-molecular-weight kininogens, to human endothelial cells. Blood 78(Suppl 1):75a.

TCM

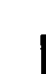

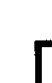

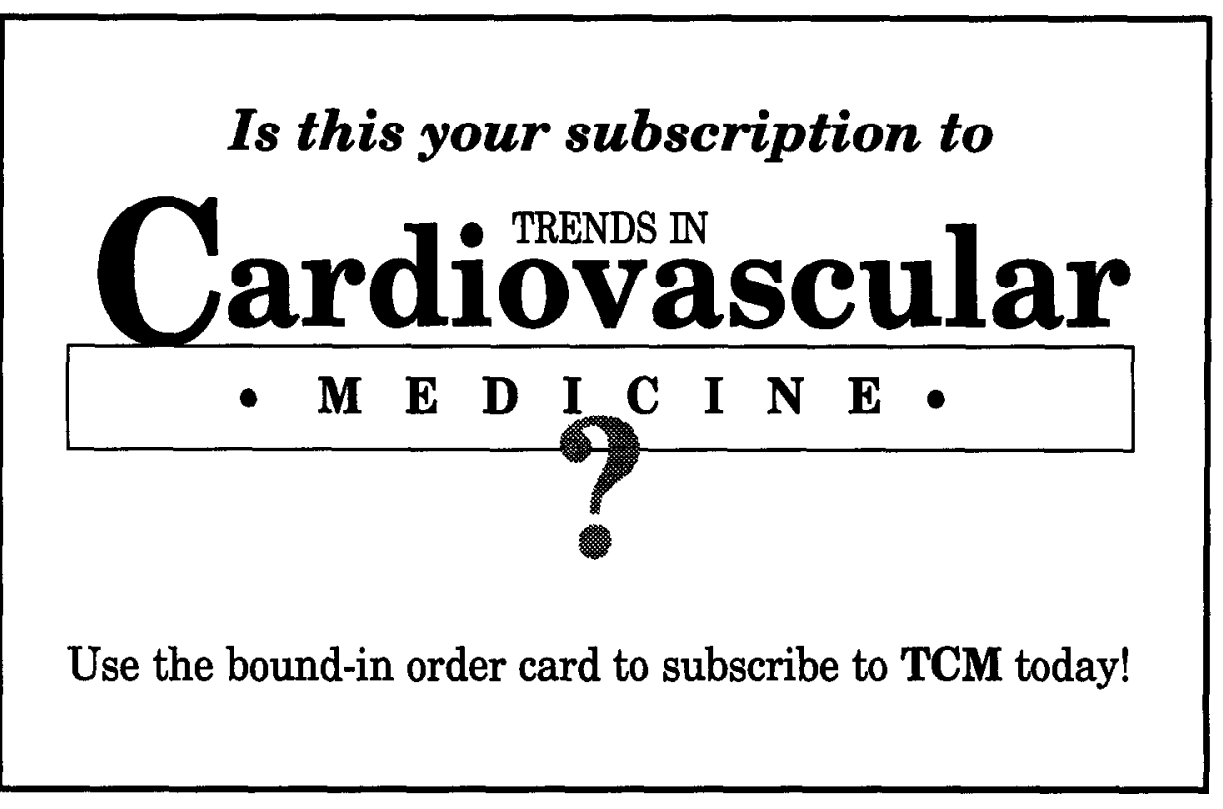

